\title{
IMPROVEMENT OF SOLID WASTE MANAGEMENT: ORGANIZATIONAL AND TECHNOLOGICAL ASPECTS
}

\author{
Irina Minakova* Tatyana Bukreeva Bukreeva Olga Timofeeva \\ Southwest State University, Kursk, Russia
}

The paper reveals the existing problems in of solid domestic waste recycling in the developed western countries and in Russia. A direct pattern is shown: the more country developed, the more waste it processes (later wastes are reused) and composts. It is established that the existing system of solid domestic waste circulation in Russia is based on their collection and transporting for disposal in landfills and dumps. Using ineffective ways of residential solid waste disposal leads to a rapid filling of landfills, even in spite of small volumes of incoming wastes and significant areas allocated for their disposal. Taking into account the specifics of a curtain territory, the structural and technological recommendations for improving residential solid waste management in the regionbased on of the method of complex processing of residential solid waste are proposed.

Key words: Solid waste circulation, Selective waste collection, Secondary materials processing

\section{INTRODUCTION}

Structural changes in industrial production and living standards, the urbanization process necessitate the study of qualitative and quantitative changes in wasteproduction and consumption. At present, more than 50 billion tons of waste have accumulated in Russia, 14\% of this volume is solid domestic waste (SDW). The growth of unauthorized burial places not only leads to environmental degradation, but also has a significant impact onhuman health, increasing morbidity and mortality. It is necessary to create an effective system of solid waste management for reducing the negative impact of waste.

State and market mechanisms for regulating waste production and consumption are studiedin the papers ofA.V. Ivanova [06], A.M. Malinina [09], G.S. Ferrard [04] and others.

Issues of solid waste management planning programs are disclosed by L.Y. Shubov [14], O.N. Borisov [14] and others.

The research purposeis to study the solid waste circulation problems in the modern economy and to develop some recommendations for improving the regional solid domestic waste management system.

The research is based on the theory and methodology of system analysis of socio-economic processes.

\section{RESULTS AND DISCUSSIONS}

The average volume of solid waste production in the EU countries is $513 \mathrm{~kg}$. [19]. The highest amount of solid wastes is generated in Denmark - $833 \mathrm{~kg}$, the smallest - in Poland (316 kg), in the USA - $700 \mathrm{~kg}$, in Russia $200 \mathrm{~kg}$. [18]. Despite the fact that in Russia the level of solid waste production is much lower than in more developed countries, but because of the undeveloped solid domestic waste management system, the problem of waste processing and recycling remains relevant.

At the same time, modern technologies in waste utilization and recycling allow reducing their volumes, reducing the impact on the environment, and also gaining economic benefit by reducing the use of fossil resources, saving energy during processing and second materials recycling. Such technologies are quite expensive, so only countries with developed economies can afford to use such them.

The highest results in solid waste management were achieved by the western developed countries. According to the US Environmental Protection Agency (EPA) [03], in the USA, has been used not onlyspecially equipped landfills for waste disposal, incineration in order to reduce the amount of dumping areas, waste export to other countries, but also methods that allow to reduce the amount of waste generation, mainly through the development of products containing less raw materials for subsequent disposal; processing (recycling) and composting (later used as a fertilizer), thereby obtaining additional profit. The main methods of waste disposal are: burial in the equipped areas - landfills, processing, including composting and burning $[02,06,15]$.

Solid waste incineration is the most common process oforganized waste disposal. Despite the fact that it is not the environmentally friendly method for the environment (emissions of harmful substances are formed), it allows to reduce the waste volume disposed in landfills, and also to use waste as a source of heat and electricity.

The more environmentally friendly method than burning at incineration plants ispyrolysis, a thermal decomposition of solid waste at elevated temperatures in vacuum or nitrogen gas. 
A separate problem is a treatment of biodegradable waste. Composting is the most common method of processing and recycling for producing organic fertilizers. It is also possible to use biodegradable wastes to produce biogas by landfill-based anaerobic digestion [12].

Automobile accumulators are the most recycled product, on the second place - copy paper grade A (white office paper), on the third - steel containers (tins, capacities).

Despite the fact that polyethylene HDPE and PET bottles are processed only in the amount of $29 \%$ and $28 \%$ respectively, while the potential for their use is great. There are a sufficient number of technologies and applications for plastic waste. According to the European Commission on the subject of plastic waste in the environment [11], the percentage of plastic packaging increased by 40\% from 1997 to 2006, while the volume of paper and cardboard wrapper products increased by $24 \%$, glass and metal - by only $2 \%$. According to the research conducted by the State Duma Committee for Natural Resources, Nature Management and Ecology, at present the Russian packaging market is one of the most promising in the world [16].

Russia is among the top ten countries in terms of the volume of packaging produced. Packaging and wrapping materials market ranges from $\$ 15$ billion to $\$ 25$ billion a year, and it annually grows by $10-12 \%$. On average, in Russia consumption of packaging is about $50 \mathrm{~kg} / \mathrm{capita}$ per year. In large cities, the volume of packaging materials disposed in landfills is $30-60 \%$ of all solid waste. And this percentageisgrowing [17].

The percentage of small and medium enterprises in packaging and wrapping materials business is quite high (in various segments it reaches 40-60\%). Such a rapid growth in packaging and wrapping materials production led to the problem of recycling and processing of packaging waste. Every year in Russia, several tens of millions of tons of packaging and wrapping materials are produced (and imported), and as a result, the volume of packaging waste is also measured in millions of tons.

According to a World Green Packaging report [20], plastics will account for $10.6 \%$ of the recycled packaging market by 2020 - up from $6.9 \%$ in 2010 and $8.5 \%$ in 2015. This increased demand will be fuelled by greater processing volumes of recycled material and increased collection activity, it says. This growth is stipulated by the fact that recycling rates for plastic packaging are much lower compared to paper and metal packaging. By 2020, the total market volume of recycled plastic packaging will be worth $\$ 26$ billion, the largest market will be the Asia-Pacific region ( $\$ 10.7$ billion), followed by Western Europe (\$ 6 billion) and the United States (US $\$ 4.6$ billion).

The development of modern technologies is aimed not only at packaging waste recycling, but also to reduce its quantity, or more precisely, to reduce its weight (Table1) [08].
According to the Table 1, packaging weight has significantly decreased. The technical decrease in packaging weight has now reached its maximum [13].

In 2006 in the USA was developed a technology of plastic bottles production with $100 \%$ used polyethylene, $25 \%$ of which are plastic waste from the 'garbage island' in the Pacific Ocean. The quality resulting from this technology is no different from the HDPE quality plastic manufactured from the original raw materials.

In addition, in recent years much attention has been paid tonew types of packaging made of photo-, moisture- and biodegradable or self-degrading polymer materials. Biodegradable materials break down quickly (from several weeks to several months) under the influence of atmospheric factors and the sun's rays into low molecular weight fragments that do not damage the environment and human health. This process occurs due to the introduction of special functional additives into a polymer. However, the selection and preparation of such additives, as well as the methods for their introduction, are very expensive and require significant preliminary work.

There is a direct pattern: the more country developed, the more waste it processes (later wastes are reused) and composts. A small exception is Germany and the United States. According to the Human Development Report 2012 [05], GNI per capita (PPP) in Germany is 35.3 thousand dollars and the level of processing is $66 \%$, while the US GNI per capita is 47 thousand dollars, and processing is only $34 \%$. Despite the fact that this is not the best indicator, more than 7 million tons of metal (including aluminum, steel and mixed metals) were received in 2012 as a result of the USA's processing, greenhouse gas emissions for a total of 25 million tons were prevented, which is equivalent to reducing of 5 million vehicles per year.

As a result of the conducted research it was established that the existing system of solid waste circulation is based on their collection, exportation and disposal in landfills, dumps. In connection with the use of ineffective ways of dumping solid waste, there is a rapid filling of district dumps, even in spite of small volumes of incoming solid waste and significant areas allocated for their disposal. Studies show that the most effective methods of handling solid waste are selective collection with the recovery of secondary raw materials, hazardous and 'other' wastes combined with the maximum processing of secondary raw materials in new products or obtaining energy.

Figure 1 presents a solid waste management scheme based on selectivewaste collection [10].

The proposed schemedistinguishes two directions of waste sorting and processing: the first is extraction from the total mass of secondary raw materials; the second is the sorting, decontamination and full processing of other wastes, hazardous waste (mercury lamps, batteries, and oils), large-sized garbage, as well as electrical equipment in the waste sorting complexes. 
At the initial stages of introduction of selective waste collection, the main pressure will fall on the second direction - sorting of inseparably collected waste at the waste sorting stations.

Gradually, the opportunity and accessibility for the population to use separate waste collection will equalize two directions and in the future, the main volume of secondary raw materials will be obtained in the first direction, i.e. waste will be sorted independently by the population.

At the same time, it is very important that housing and communal services are responsible to organize collection, processing, neutralization and disposal in the second direction, and in the first direction this responsibility lies on specialized commercial enterprises operating in the secondary materials market. Consumers of secondary raw materials are enterprises of the Kursk region and nearby regions.
Special block containers, the prototype of which is the patent for the utility model 92854, B65F 5/00, B65F $9 / 00,2010$, should be used for selective collection[07, 01]. Unlike the prototype, the proposed block container (Figure 2) has the following differences: equipping the block-container with a compactor that allows to reduce the volumes of secondary raw materials; use of special containers for hazardous waste collection; the division of the main compartment with containers into such four blocks as secondary raw materials, hazardous and other types of waste, waste storage, a compartment for collecting bulky waste and electrical equipment.

A compactor device will allow reducing the number of trips of special transport, i.e. reducing the costs for fuel and lubricant materials, as well as pollutant emissions into the atmosphere.

Table1: Evolution of packaging weight

\begin{tabular}{|c|c|c|c|c|c|}
\hline Type of packaging & $1970-\mathrm{s}$ & $1990-\mathrm{s}$ & 2000 & 2008 & Deviation \\
\hline Bottles for washing-up liquids (1 liter) & 120 & 67 & 50 & 43 & $64,17 \%$ \\
\hline Soup packaging (400 g) & 69 & 57 & 55 & 49 & $28,99 \%$ \\
\hline Yoghurt cups (165 g)) & 7 & 5 & 5 & 4 & $42,86 \%$ \\
\hline Plastic bottles for carbonated drinks (2 liters) & 58 & 58 & 43 & 40 & $31,03 \%$ \\
\hline Metal cans for drinks (330 ml) & 60 & 21 & 15 & 14 & $76,67 \%$ \\
\hline Glass beer bottles (275 g) & 450 & 450 & 325 & 176 & $60,89 \%$ \\
\hline Glass milk bottles (0,568 I) & 397 & 230 & 230 & 186 & $53.15 \%$ \\
\hline
\end{tabular}

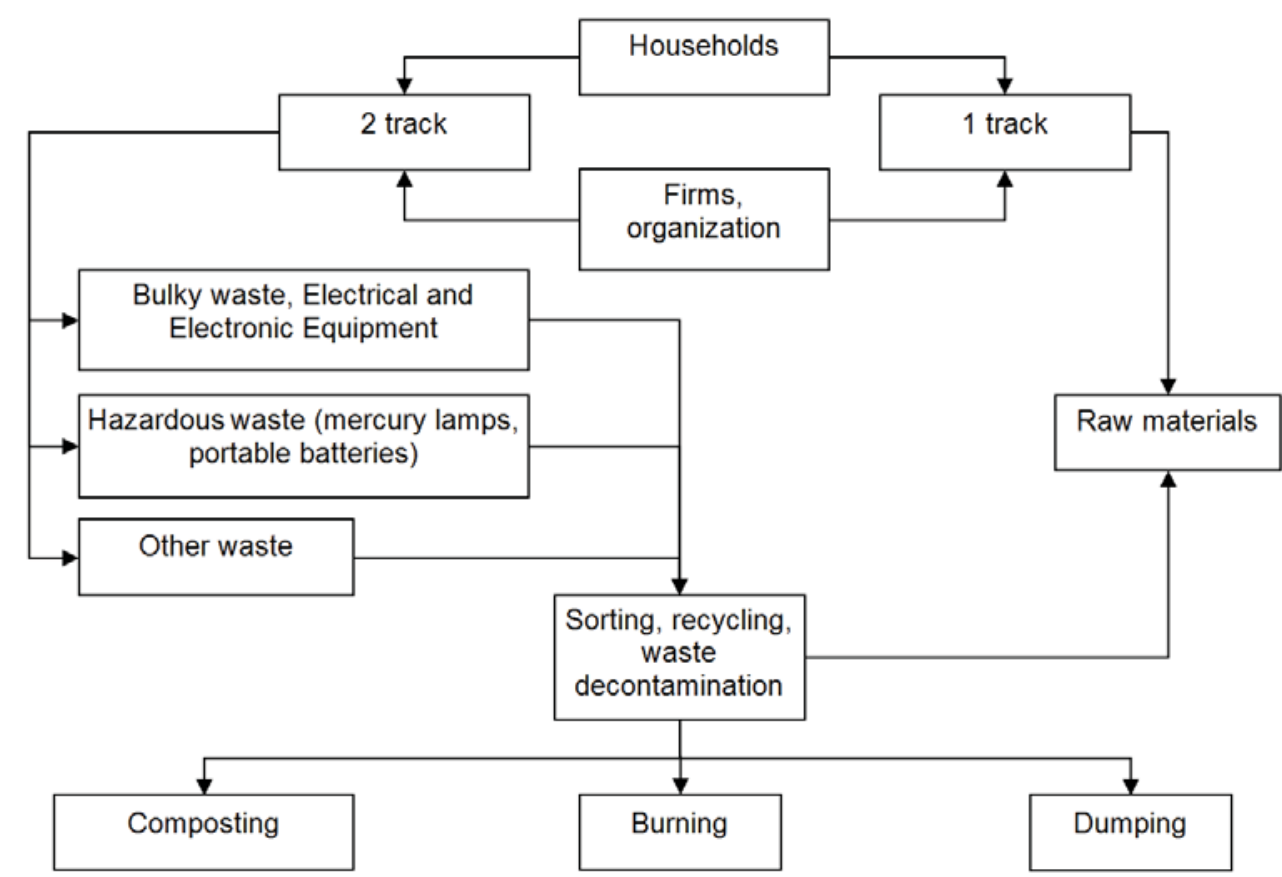

Figure 1: Solid waste management scheme based on selective waste collection 


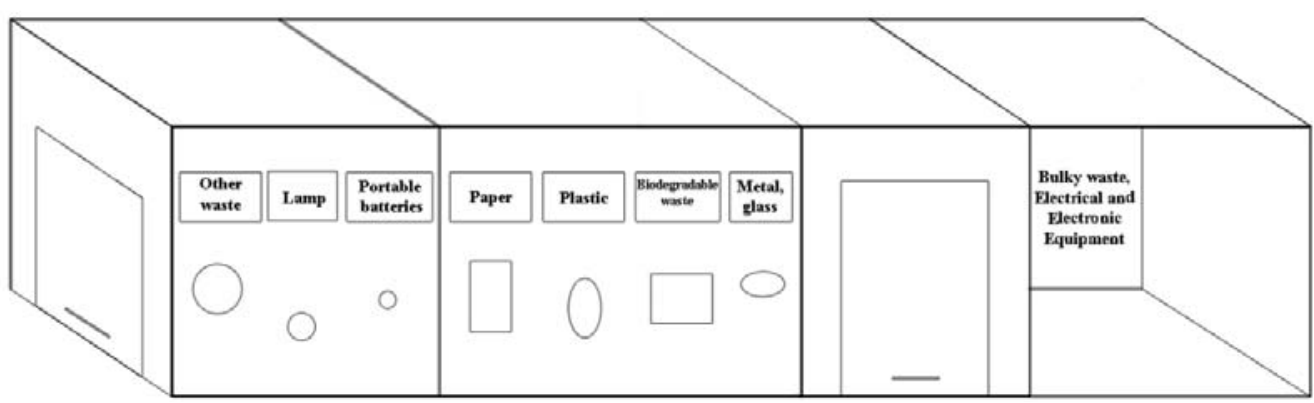

Figure 2: Container yard for selective waste collection

Dividing into two blocks is necessary to limit access of public services to secondary raw materials. After pressing, secondary raw materials are sent to the storage compartment, only specialized enterprises servicing this site should have access to it. It is not necessary to equip every site with storage unit, bulky waste and electrical equipment waste compartment.

An enclosed shed with special loading hatches for each type of waste and a closed unloading opening is installed on the waste collection site. Hatches are made with the ability to sort waste by the population by material type and size, have different loading enters and plaques indicating the type of waste. Loading hatches can be closed withautomatic doors. Outside the shed a large-sized waste compartment is made. Inside the shed, under the loading hatches, there are mobile waste containers and secondary material tanks equipped with filling sensors, and storage compartments for each type of secondary raw material and compartments for empty containers are also placed here.

When the containers are full, service organization replaces it with empty containers from the curtain compartment. By filling secondary raw materials container, service organization carries out pressing and moving into the corresponding storage compartment. Removal of secondary raw materials is made by the accumulation of a certain volume in storage compartments of temporary deposit. Loaded containers and tanks are moved through the discharge port to the vehicle. Wastes are exported in accordance with sanitary requirements and regulations. Secondary raw materials: plastic, metal, glass, waste paper are exported to consumers directly from the collection point, bypassing waste-processing and waste sorting plants and landfills, which contributes to the self-sufficiency of the container site. Hazardous waste (mercury lamps and batteries) are sent to special enterprises for their neutralization and disposal.

An enclosed shed provides sanitary protection of the container from atmospheric precipitation, animals and birds that can spread infectious and diseases to human, and protection from blowing up waste and garbage by wind.
Advantages of this site are:

- active involvement of the population in solid waste sorting process and use of secondary materials;

- inculcate a proper attitude to waste disposaland preservation of secondary resources to children;

- high quality of collected raw materials;

- reducing waste disposal costs, transportation of secondary raw materials (consumers of secondary raw materials export it themselves);

- extraction of hazardous waste (mercury lamps and batteries) improves safety at waste sorting plant.

\section{CONCLUSION}

The proposedsolid waste management schemebased on selective waste collection will provide:

- social effect (new jobs (sorters, refuse carriers, due to increased production volumes at existing processing enterprises);

- ecological effect (reducing the volumes of waste disposal at the landfill;increasing consumers' environmental awareness and culture);

- economic effect (reduction of waste transportation costs (reduction of waste disposal costs in landfills and transportation costs (due to waste compacting, profits of companies organizing waste sorting and processing).

The proposed waste management scheme should be supplemented by a special program to motivate adults and inculcate a proper attitude to waste sorting to children. For example, supermarkets can place containers for collecting finger batteries, special machines for collecting plastic bottles and aluminum cans. For the delivered used products and batteries, stickers ('coupons') are issued, the booklet filled with these stickers can be exchanged for a gift (toy, sweet, movie ticket, attractions, purchase discount, etc.). This program can be financed from the municipal budget by funds aimed at sanitation cleaning of the city. 
The introduction of residential solid waste sorting will reduce the amount of waste buried, and also receive valuable raw materials for economic activities. The practical significance of the research is the possibility of applying its findings and recommendations to the management of regional socio-economic systems in the process of developing of strategic and tactical programs for solid waste management system.

\section{REFERENCES}

1. Balmachnykh V.A., Makarov R.B., Shishov O.V The mobile device for separate collecting and transportation of household waste: patent for useful model 54577, B65F/ (in Russian).

2. Devyatkin V.V. (2009). Waste management: domestic and foreign experience // Ecological bulletin of Russia. 2009. No 2.P. 37 - 41.

3. Environmental Protection Agency AnGhníomhaireacht um ChaomhnuComhsaoil Municipal Solid Waste - Pre-treatment \& Residuals Management An EPA Technical Guidance Document / https://www. epa.ie/pubs/advice/waste/municipalwaste/EPA MSW_Pre-Treatment_Guide_final\%20Amended. pdf.

4. Ferrara G.S. (2011). Problems, tendencies and ways of regulation of activities for the address with waste //Scientific sheets of BELGU. Series: History. Political science. Economy. Informatics. No 7-1 (102). http://cyberleninka.ru/article/n/problemy-tendentsii-i-sposoby-regulirovaniya-deyatelnosti-po-obrascheniyu-s-othodami (in Russian).

5. Index of human development and its components. Report on development of the person of 2009. http:// www.un.org/ru/development/hdr/2009/ (in Russian).

6. Ivanov A.V. (2007). Treatment of municipal solid waste, organizational, technological and financial and economic aspects (Russian and foreign experience) / Research Center of economic problems of improvement and the address with waste. - Kaliningrad (in Russian).

7. Korotkin E.M. The container platform for separate collecting municipal solid waste: patent for useful model 92854, B65F 5/00, B65F 9/00, 2010/ (in Russian).

8. Lyubeshkina E.G. Packing processing. Imperishable boxes, jars, bottles / http://www.kursiv.ru/kursivnew/ paket_magazine/archive/34/8.php\#text (in Russian).

9. Malinin A.M. Chepiga P.N. (2010). State and concession model of regional government sphere of the address of industrial and consumption waste //Bulletin of the Russian Academy of Natural Sciences (St. Petersburg). No4. P. 51-55 (in Russian).
10. Minakova I.V., Timofeeva O.G. (2015). Institutional innovations in a control system of the address of municipal solid waste in the region // In the world of discoveries. No10 (70). P. 118-125 (in Russian).

11. Municipal waste generated and treated / http://epp. eurostat.ec.europa.eu/portal/page/portal/waste/ data/sectors/municipal_waste.

12. Pan L.N. Ekologiya and technological processes of modern methods of processing of municipal solid waste. Agency of scientific and technical information Scientific and technical library / http://sciteclibrary.ru/ rus/catalog/pages/1951.html (in Russian).

13. Recycling international /http://www.recyclinginternation.com.

14. ShubovL.Ya.,Borisova O.N., Doronkin I.G.(2011). Technologies of the address with waste: advantages and shortcomings, myths and realities//Municipal solid waste. No10. P. 10-15 (in Russian).

15. Sokolova N.R.,Kozlov G.I. (2011). Removal of solid waste in Russia: the review of the main regional problems and the made decisions //Municipal solid waste. No5. P. 54-57 (in Russian).

16. State Duma Committee on Natural Resources, Environment and Ecology: official site / http://www.komitet2-21.km.duma.gov.ru/site. xp/053048124053048052.html (in Russian).

17. The analytical report by results of the analysis of the commodity market of services in export, processing and burial of municipal solid waste / http:// www.fas.gov.ru/analytical-materials/analytical-materials_12334.html (in Russian).

18. The truth about recycling / http://www.economist. com/node/9249262.

19. Timofeeva O.G.,Minakova I.V. (2013). To a question of adaptation of institutional bases of utilization of a plastic container and packing in the developed countries to conditions of the Russian economy //YuZGU News. - Kursk.No1. P.215-219 (in Russian).

20. World Green Packaging/http://www.greenerpackage.com/recycling/world_demand_green_packaging_reach_2012.

Paper submitted: 07.02.2018.

Paper accepted: 14.03.2018.

This is an open access article distributed under the CC BY-NC-ND 4.0 terms and conditions. 